\title{
Dairy productivity of Holstein cattle with different genotypes of the paraoxonase-1 (PON1) gene
}

\author{
Natalia Safina*, Shamil Shakirov, Elza Gaynutdinova, and Ziliya Fattakhova \\ Tatar Scientific Research Institute of Agriculture "Kazan Scientific Center of Russia Academy of \\ Sciences", 48, Orenburg tract st., Kazan, 420059, Russian Federation
}

\begin{abstract}
The aim of the work was to study the traits of dairy productivity of Holstein heifers with different genotypes of the paraoxonase-1 (PON1) gene. The research was conducted in 148 animals of Integrated Agricultural Production Centre "Stud farm named after Lenin" of Atninsky district of the Republic of Tatarstan. Genotyping of cattle was carried out by the PCR-RFLP method at the laboratory of the Department of Agrobiological Research of Tatar Scientific Research Institute of Agriculture, FRC Kazan Scientific Center, Russian Academy of Sciences. The results of allele and genotype calling of the PON1 gene showed that the study population is polymorphic and differs in genetic biodiversity. During the analysis of daity productivity, qualitative composition of milk and lactational activity, it was found that cow-heifers with the GG genotype of the PON1 gene were superior to animals with other genotypes in all the test parameters. Thus, it follows that the GG genotype of the PON1 gene has a positive effect on the economic characters of cattle, which can be used in breeding in the future.
\end{abstract}

\section{Introduction}

The indicator of dairy productivity is expressed by a curvilinear pattern during lactation, which is called the lactation curve. The lactation curve of dairy cattle starts from the period of milking, increases from the beginning to the peak of lactation, and then decreases until the dry period comes. In order to develop an appropriate herd management strategy, it is necessary to know the milk yield, the lactation curve parameters and the factors that affect the lactation persistency. Increasing the lactation persistency in dairy cows has a significant positive effect on animal health, fertility and herd productivity. Since cows face negative energy balance and other health concerns during the peak of lactation, the total milk yield can be increased by improving the lactation persistency [1].

Persistence is an important indicator that characterizes the lactation activity of cows, the value of which points to the ability of the animal to maintain dairy productivity at a high level for as long as possible after reaching the peak of lactation [2]. Milk yield, qualitative composition of milk, and lactation curve may vary depending on the genotype, and therefore stability may change positively or negatively. Animals with a stable lactation curve give milk with less stress of the body. They are more stress-resistant and differ in the

\footnotetext{
${ }^{*}$ Corresponding author: natysafina@gmail.com
} 
duration of economic use and high food convertion [3]. The level and nature of lactation activity, all other things being equal, are the determining factors of dairy productivity of cows per lactation.

Paraoxonase-1 (PON1) is a glycoprotein with a molecular weight of $38-45 \mathrm{kDa}$. It is a $\mathrm{Ca}+$ - dependent esterase associated with apolipoprotein A-1 (apoA-1) in high-density lipoproteins (HDL) $[4,5]$. PON1 is synthesized exclusively in the mammalian liver and is secreted into the blood [6]. PON1 protein can interact with insulin, steapsin, growth hormone, lipoprotein lipase and leptin [7,8].

The bovine PON1 gene encoding the protein of the same name is located on chromosome 4 and has a length of $33168 \mathrm{bp}$. The replacement (Arg $\rightarrow \mathrm{Gln}, \mathrm{A} / \mathrm{G})$ at position 221 in the $828 \mathrm{bp}$ fragment of the PON1 gene promoter region is associated with an acute phase reaction, which makes this marker interesting for the selection of cows with the best response to inflammatory processes in the body [9, 10]. Identification of different genotypes will make it possible to assess the effect of the PON1 gene polymorphism on the economic characters of cattle, which can be used in breeding in the future.

The aim of the research was to study the effect of the PON1 gene polymorphism on the characters of dairy productivity of Holstein cattle.

\section{Materials and methods}

The research was carried out in 2019-2020 in Integrated Agricultural Production Centre "Stud farm named after Lenin" of Atninsky district of the Republic of Tatarstan. 148 Holstein cow-heifers were the object of the study. The biomaterial was collected into K3EDTA preservative tubes containing EDTA anticoagulant (APEXLAB, China). DNA extraction was carried out in the laboratory of Agrobiological Research of Tatar Scientific Research Institute of Agriculture, FRC Kazan Scientific Center, Russian Academy of Sciences using a ready-made "AmpliPrime DNA-sorb-B" kit (NextBio, Russia) according to the shop instruction. To detect the SNP of the PON1 gene (Arg $\rightarrow$ Gln) by the PCR-RFLP method, a reaction mixture containing purified DNA and primers with an oligonucleotide sequence (SibEnzyme, Russia):

Forward: 5' - CGGTAATCCCTGAAGAATGC -3'

Reverse: 5' - GCACTTCCTACCCCTGCTTTG -3' [9]

was amplified in programmable thermal cyclers "T-100 Thermal Cycler" and "My Cycler" (Bio-Rad, USA). The temperature-time regimes were as follows: denaturation $-5 \mathrm{~min}$. at $94{ }^{\circ} \mathrm{C}$; annealing $(40$ cycles $)-60 \mathrm{sec}$. at $94{ }^{\circ} \mathrm{C}, 60 \mathrm{sec}$. at $58{ }^{\circ} \mathrm{C}, 60 \mathrm{sec}$. at $72{ }^{\circ} \mathrm{C}$; elongation $-10 \mathrm{~min}$. at $72{ }^{\circ} \mathrm{C}$. Further cleavage of PCR samples was carried out in the presence of restriction endonuclease Bsc4 I (Bacillus schlegelii 4) (SibEnzyme, Russia) [11], BSA and buffer W (SibEnzyme, Russia) for $16 \mathrm{~h}$ at $55^{\circ} \mathrm{C}$. Electrophoretic separation was performed in a horizontal chamber in $2.6 \%$ agarose gel in the presence of ethidium bromide $(10 \%)$. The identified polymorphism was visualized and documented in the "Gel\&Doc" system (Bio-Rad, USA). The identified polymorphism was visualized and documented in the "Gel\&Doc" system (Bio-Rad, USA).

The frequency of occurrence of allelic variants and genotypes was calculated according to the guidelines [12]. The significance of the variability between the expected and observed distribution of genotypes of the PON1 gene was tested by Pearson's chi-squared test $\left(\chi^{2}\right)$ and for compliance with the Hardy-Weinberg law of genetic equilibrium in the population. Experimental groups were formed from the animals in accordance with the established genotypes and association studies with the economic characters of cattle were conducted.

Data on milk yield and lactation activity were taken from the research and information system "SELEX. Dairy cattle w.6.1.0.0." (AWS Plinor, Russia). The analysis of the 
qualitative composition of milk was carried out on CombiFoss ${ }^{\mathrm{TM}} 7$, MilkoScan ${ }^{\mathrm{TM}} 7 \mathrm{RM}$, Fossomatic 7 TM 7 in JSC "Elite" of Vysokogorsky district of the Republic of Tatarstan.

Comparison of milk yield was carried out by the ratio of milk yield of the second phase of lactation to the first one. This coefficient of lactation stability is used to assess the level of milk yield decline during the productive period. The coefficient of lactation stability in high-producing cows with pronounced high milk yields reaches $90-99 \%$, and in cows with decreasing milk yield $-70-80 \%$.

The coefficient of usefulness of lactation was also calculated. The coefficient of usefulness is $70 \%$ and more in cows with leveled lactation, and $50 \%$ and less in cows with declining one. The results obtained in the course of scientific research are processed by the biometric method.

\section{Results and discussion}

As a result of DNA testing, all alleles and genotypes of the paraoxonase-1 gene were detected (table 1). The allele frequency was $\mathrm{A}-0.564$ and $\mathrm{G}-0.436$. The genotypes had the following distribution: AA $-31.8 \%$ (47 animals), AG - 49.3\% ( 73 animals), GG $18.9 \%$ (28 animals). The chi-square test $\left(\chi^{2}\right)$ showed that the genetic equilibrium in the population according to the Hardy-Weinberg law is not upset.

Table 1. The occurrence of alleles and genotypes of the PON1 gene in cattle stock

\begin{tabular}{|c|c|c|c|c|c|c|c|c|c|}
\hline \multirow{3}{*}{ Frequency } & \multicolumn{6}{|c|}{ Genotype frequency } & \multirow{2}{*}{\multicolumn{2}{|c|}{$\begin{array}{c}\text { Allele } \\
\text { frequency }\end{array}$}} & \multirow{3}{*}{$\chi^{2}$} \\
\hline & \multicolumn{2}{|c|}{$\mathrm{AA}$} & \multicolumn{2}{|c|}{ GA } & \multicolumn{2}{|c|}{$\mathrm{GG}$} & & & \\
\hline & $\mathrm{n}$ & $\%$ & $\mathrm{n}$ & $\%$ & $\mathrm{n}$ & $\%$ & $\mathrm{~A}$ & $\mathrm{G}$ & \\
\hline Observed & 47 & 31.8 & 73 & 49.3 & 28 & 18.9 & \multirow{2}{*}{0.564} & \multirow{2}{*}{0.436} & \multirow{2}{*}{0.001} \\
\hline Expected & 47 & 31.8 & 72 & 49.2 & 29 & 19.0 & & & \\
\hline
\end{tabular}

Previously published data from researchers of the PON1 gene polymorphism are also indicative of the dominance of the A allele over the $\mathrm{G}$ allele in various cattle breeds $[9,11$, 13]. Animals of the heterozygous GA genotype typically prevailed in number - over $50.0 \%$ of the livestock. However, according to other scientists, the AA genotype was practically absent in the population of crossbred Simmental cows. The GG genotype reached $84.0 \%$, the allele frequency was $\mathrm{G}-0.920$ and $\mathrm{A}-0.080$ [14].

Our further research was aimed at studying the relationship of polymorphic forms of the PON1 gene with the signs of milk productivity in Holstein cow-heifers. The groups were formed according to the identified genotype.

The analysis of dairy productivity and qualitative composition of milk (table 2) showed that cows with the GG genotype had the highest milk yield for the first standard lactation (305 days). The significant difference with the AA genotype was $1025.5 \mathrm{~kg}$ (13.2\%), and with the GA genotype - $1370.9 \mathrm{~kg}(17.7 \%)$.

Table 2. Association of the PON1 gene polymorphism and traits of milk productivity of Holstein cows

\begin{tabular}{|l|c|c|c|}
\hline \multirow{2}{*}{\multicolumn{1}{|c|}{ Traits }} & \multicolumn{3}{|c|}{ Genotype } \\
\cline { 2 - 4 } & AA $(\mathrm{n}=47)$ & GA $(\mathrm{n}=73)$ & GG $(\mathrm{n}=28)$ \\
\hline Milk yield, $\mathrm{kg}$ & $6715.3 \pm 126.9$ & $6369.9 \pm 132.9$ & $7740.8 \pm 225.8 * * *$ \\
\hline Fat, \% & $3.74 \pm 0.06$ & $3.78 \pm 0.05$ & $3.76 \pm 0.08$ \\
\hline Protein, \% & $3.29 \pm 0.04$ & $3.35 \pm 0.02$ & $3.29 \pm 0.04$ \\
\hline Milk fat yield, $\mathrm{kg}$ & $251.2 \pm 4.9$ & $240.8 \pm 6.1$ & $291.1 \pm 10.1 * * *$ \\
\hline
\end{tabular}




\begin{tabular}{|l|l|l|l|}
\hline $\begin{array}{l}\text { Milk protein yield, } \\
\mathrm{kg}\end{array}$ & $220.9 \pm 4.2$ & $213.4 \pm 4.8$ & $254.6 \pm 8.6 * * *$ \\
\hline
\end{tabular}

$* * *-\mathrm{p}<0.001$, a difference between the highest and the given indicator

The same group of homozygous individuals with the GG genotype was characterized by a high yield of milk fat and milk protein. The advantage in these parameters over other genotypes was $39.9 \mathrm{~kg}(13.7 \%)$ and $33.7 \mathrm{~kg}(13.2 \%)$ over the AA genotype and $50.3 \mathrm{~kg}$ $(17.3 \%)$ and $41.2 \mathrm{~kg}(16.2 \%)$ over the GA genotype, respectively.

No significant differences were found between groups with different genotypes of the PON1 gene in terms of fat and protein content.

The lactation curve is one of the additional characteristics of dairy productivity. Figure 1 shows curves representing standard 305 day lactation of cow-heifers with different PON1 genotypes that have individual changes in milk yields depending on the lactation period.

The analysis revealed that depending on the genotype, the parameter of average monthly milk yield and the nature of lactation curves change. All the animals under study are characterized by smooth lactation curves without jumps. On this basis, the cow-heifers of all genotypes of the paraoxonase- 1 gene can be attributed to the first type according to A.S. Yemelyanov (1953) [15].

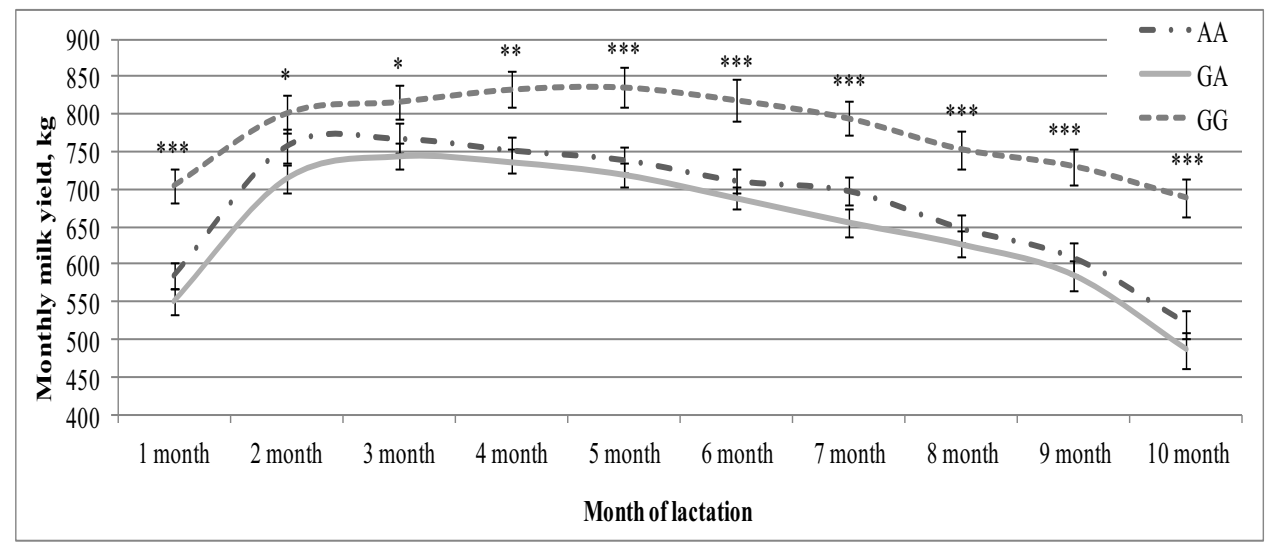

Fig. 1. Lactation curves of the milk productivity of heifers with different PON1 genotypes $\left(^{*}-\right.$ $\mathrm{p}<0.05 ; * *-\mathrm{p}<0.01 ; * * *-\mathrm{p}<0.001$ a difference between the highest and the given indicator)

Consequently, the study population of Holstein cattle has a strong constitution and consistency of dairy productivity. Animals with the homozygous GG genotype show high milk yield throughout lactation, the peak occurs at 4 and 5 months after calving (833.3 and $836.08 \mathrm{~kg}$ ). The average monthly milk yields of animals with AA and GA genotypes do not have statistically significant differences except for the $3^{\text {rd }}$ month of lactation, which is the peak of productivity in both groups. It is worth noting that the population under study is characterized by stable milk yields and high productivity throughout the first lactation, which is illustrative of the usefulness of the diet and good preparation for calving.

It was recorded that throughout lactation stable superiority in dairy productivity was assigned to cow-heifers with the GG genotype, the worst indicators were established in animals with the GA genotype. Individuals with the AA genotype distinguished themselves with average results as evidenced by the coefficient of lactation decline, indicating a relatively low level of average monthly milk yields showed in Table 3. This indicator is significantly lower in the group of individuals with the GG genotype of the PON1 gene than in the GA and AA groups by 3.46 and $2.73 \%$, respectively. 
The stability and usefulness coefficients of lactation were calculated for each group to fully assess the persistence of milk yield of cow-heifers with different PON1 genotypes.

Table 3. Characteristics of lactation curves of the dairy productivity of heifers with different PON1 genotypes

\begin{tabular}{|l|c|c|c|}
\hline \multirow{2}{*}{ Indicator of lactation } & \multicolumn{3}{|c|}{ Genotypes } \\
\cline { 2 - 4 } & $\mathrm{AA}$ & $\mathrm{GA}$ & $\mathrm{GG}$ \\
\hline Coefficient of decline, \% & $5.83 \pm 0.02$ & $6.56 \pm 0.02$ & $3.10 \pm 0.01^{* * *}$ \\
\hline Coefficient of stability, \% & $84.2 \pm 2.58$ & $84.5 \pm 1.78$ & $93.6 \pm 1.76^{* * *}$ \\
\hline Coefficient of usefulness, \% & $77.0 \pm 1.20$ & $76.0 \pm 1.05$ & $78.4 \pm 1.47$ \\
\hline
\end{tabular}

$* * *-p<0.001$, a difference between the highest and the given indicator

During the experiment it was found that cow-heifers with the GG genotype had high stability coefficients of lactation usefulness - 93.6 and $78.4 \%$. However, the same indicators of animals with AA and GA genotypes, despite the fact that they were lower than those of GG, are considered high by physiological standards and show a minimum level of productivity decline throughout lactation.

\section{Conclusion}

The results of the SNP study of the PON1 gene showed that the population under study is characterized by genetic biodiversity and is represented by all alleles and genotypes. The genetic equilibrium according to the Hardy-Weinberg law is not upset. The maximum number of individuals is represented by the heterozygous GA genotype $-49.3 \%$. The distribution of alleles is dominated by the A allele - 0.564. Cow-heifers with the GG genotype outperformed cows with other genotypes of the PON1 gene in dairy productivity. Milk yield for lactation of 305 days was $7740.8 \mathrm{~kg}$. The maximum yield of milk fat and milk protein was recorded in the same group of animals - 291.1 and $254.6 \mathrm{~kg}$, respectively. Following the results of lactation activity, it may be concluded that cows with the GG genotype are characterized by high average monthly milk yields, high lactation stability and a low lactation decline coefficient. All the animals under study are characterized by smooth lactation schedules without jumps and have high expressed milk yields.

Thus, it follows that the GG genotype of the PON1 gene has a positive effect on the economic characters of cattle, which can be used in breeding in the future.

\section{Acknowledgments}

This research was supported by FASO Russia project "Mobilizing the genetic resources of plants and animals, creating innovations that ensure the production of biologically valuable food products with maximum safety for human health and the environment" AAAA-A18118031390148-1.

\section{References}

1. D. Do, N. Bissonnette, P. Lacasse, F. Miglior, M. Sargolzaei, X. Zhao, E. IbeaghaAwemu, Journal of Dairy Science, 100 (3), 1955-1970 (2017)

2. J. Jamrozik, G. Jansen, L. Schaeffer, Z. Liu, Interbull Bulletin, 17, 64-69 (1998)

3. N.Yu. Safina, Sh.K. Shakirov, F.F. Zinnatova, Z.F. Fattakhova, E.R. Gaynutdinova and L.N. Shayakhmetova, Research Journal of Pharmaceutical, Biological and Chemical Sciences, 9 (6), 2028-2031 (2018) 
4. M.-C. Blatter, R.W. James, S. Messmer, F. Barja, D. Pometta, European Journal of Biochemistry, 211, 871-879 (1993) https://doi.org/10.1111/j.14321033.1993.tb17620.x

5. A. Gugliucci, R. Caccavello, K. Kotani, N. Sakane, S. Kimura, Clinica Chimica Acta, 415, 162-168 (2013) doi: 10.1016/j.cca.2012.10.044

6. M.I. Mackness, B. Mackness, P.N. Durrington, P.W. Connelly, R.A. Hegele, Current Opinion in Lipidology, 7 (2), 69-76 (1996) doi: 10.1097/00041433-199604000-00004

7. R.A. Curi, H.N. de Oliveira, A.C. Silveira and C.R. Lopes, Livestock Production Science, 94, 159-167 (2005) https://doi.org/10.1016/j. livprodsci.2004.10.009

8. R.A. Curi, D.A. Palmieri, L. Suguisawa, A.L.J. Ferraz, H.N. de Sliveira, L.R. Furlan, A.C. Silveira, C.R. Lopes, Livestock Science, 101, 94-100 (2006) https://doi.org/10.1016/j.livprodsci.2005.09.015

9. P.A.S. Silveira, E. Schwegler, P. Montagner, A.R.T. Krause, D.A.V. Acosta, J. Halfen, T. Garlet, C.C. Barros, M.N. Corrêa, A. Schneider, The Veterinary Journal, 205 (1), (2015) 101-103. doi: 10.1016/j.tvj1.2015.04.028

10. A. Wedel, H.W. Ziegler-Heitbrock, Immunobiology, 193 (2-4), 171-185 (1995) doi: 10.1016/s0171-2985(11)80541-3

11. P.A.S. Silveira, W.R. Butler, S.E. LaCount, T.R. Overton, C.C. Barros, A. Schneider, Theriogenology, 125, 302-309 (2019) doi: 10.1016/j.theriogenology.2018.11.024

12. E.K. Merkureva, G.N. Shangin-Berezovsky, Genetics with the fundamentals of biometrics, 400 (Moskow, Kolos, 1983)

13. A.G. Ji, Y.H. Huai, Z.K. Zhou, J.Y. Li, L.P. Zhang, S.Z. Xu, X. Gao, H.Y. Ren, J.B. Chen, Asian-Australasian Journal of Animal Sciences, 21 (8), 1097-1102 (2008) doi: https://doi.org/10.5713/ajas.2008.70717

14. J. Zhang, S. Zhao, Z. Lei, X. Wang, J. Wu, M.A. Brown, Journal of Animal and Veterinary Advances, 12 (2), 229-233 (2013) doi: 10.36478/javaa.2013.229.233

15. A.S. Emelyanov, Lactation activity of cows and its management, 97 (Vologda, Molochnoe, 1953) 